\title{
Salinity Intrusion in Interior Coast of Bangladesh: Challenges to Agriculture in South-Central Coastal Zone
}

\author{
Mohammed Abdul Baten",2, Lubna Seal2,3, Kazi Sunzida Lisa' \\ ${ }^{1}$ School of Environmental Science and Management, Independent University Bangladesh, Dhaka, Bangladesh \\ ${ }^{2}$ Unnayan Onneshan (Center for Research and Action on Development), Dhaka, Bangladesh \\ ${ }^{3}$ Department of Geography and Environmental Management, University of Waterloo, Waterloo, Canada \\ Email: a.baten@iub.edu.bd, Iseal@uwaterloo.ca, sunzida.du@gmail.com
}

Received 19 March 2015; accepted 8 June 2015; published 11 June 2015

Copyright (C 2015 by authors and Scientific Research Publishing Inc.

This work is licensed under the Creative Commons Attribution International License (CC BY). http://creativecommons.org/licenses/by/4.0/

(c) $\underset{\text { EY }}{0}$ Open Access

\section{Abstract}

This paper investigates the impacts of salinity on crop agriculture in south-central coastal zone of Bangladesh, more particularly interior coast. The coastal areas of Bangladesh, with near flat topography and location at the tip of "funnel shaped" Bay of Bengal, are susceptible to a number of natural hazards such as cyclones, tidal surges, salinity intrusion, riverbank erosion, and shoreline recession. The coastal zone of Bangladesh, especially exposed coast has come into focus in a number of policy and academic studies for salinity intrusion, but with the accelerated impacts of climate change salinity extends from the exposed to the interior coast hampering crop production. To investigate extent of salinity level in interior coast and its impact on crop agriculture, this study tested irrigation water collected in between October and December 2011 from the lower Meghna at Gosairhat upazila in Shariatpur district and interviewed experts and local farmers. This study estimated that salinity concentration of surface water was $1.3 \mathrm{dS} / \mathrm{m}$ which was $0.8 \mathrm{dS} / \mathrm{m}$ higher than the earlier estimation by ICZMP (Integrated Coastal Zone Management Plan) in 2003. The test further revealed that Chloride ion concentration in irrigation water was $500 \mathrm{ppm}$, pH level was 7.99 and concentration of Carbonate ion was $221 \mathrm{ppm}$, which were much higher than the desired level. Estimated salinity concentration has already put a threat to the crop production and a significant yield loss has already been noticed in dry season. In the changing scenario of sea level rise, it has been predicted that the increasing concentration of salinity would create more pressure to the farmer by reducing yield on one hand and threatening livelihood, income generation and food security on the other hand. Therefore, to reduce the future loss and prevent the present loss, the study recommends leaching and selecting salinity tolerant crop varieties as adaptation techniques. 


\section{Keywords}

\section{Agriculture, Bangladesh, Interior Coast, Leaching, pH, Salinity Intrusion}

\section{Introduction}

Salinity intrusion is a growing problem in the coastal areas around the globe, especially in the low-lying developing countries [1]. The problem becomes exacerbated particularly in the dry season when rainfall is inadequate and incapable of lowering the concentration of salinity on surface water and leaching out salt from soil. Coastal agriculture experiences a yield reduction or in some cases devastation due to tidal inundation and salinity [1]. Climate change associated hazards like sea level rise, cyclone and storm surge have been contributing to aggravate the problem. IPCC [2] predicts that the sea level rise is likely to persist for centuries, resulting from the process and feedback of climate, even though the concentration of Green House Gases (GHGs) is to become steady. The sea level rise is not indistinguishable in every geographical location [3]. The rise may be expected a little more in some regions than to others depending on some factors and these are not limited to some climate independent factors like land subsidence and climate dependent factors like thermal expansion. However, the climate dependent factor seems to be more influential. Moreover, the impact of sea level rise also varies depending on geographic location as well as socio-economic factors like population density, livelihood option, poor infrastructure, inadequate policy and inefficient technology.

Bangladesh, a low-lying deltaic land, is particularly vulnerable to climate change and its associated hazards [4]. The coastal areas of Bangladesh, with its near flat topography and location at the tip of "funnel shaped" Bay of Bengal, is susceptible to a number of natural hazards: cyclones and tidal surges, salinity intrusion, riverbank erosion, shoreline recession etc. [5]. Although all hazards are detrimental to agriculture, however sea level rise is likely to put the gravest threat by land submersion and salinity intrusion [6] [7]. Irrigated water demand is highly affected by salinity intrusion in surface water [8] and salt accumulation in the root zone of soil affects plant growth in coastal soil [9]. Besides constraining agricultural production, salinity limits the fresh water availability for drinking purpose and industrial production.

Coastal area of Bangladesh has already been experiencing erosion. It has been found that the sea level rise of $0.5 \mathrm{~m}$ over the last 100 years has eroded approximately $162 \mathrm{~km}^{2}$ of Kutubdia, $147 \mathrm{~km}^{2}$ of Bhola and $117 \mathrm{~km}^{2}$ of Sandwip [10]. Based on 22 years data, SAARC Meteorological Research Council (SMRC) found that the sea level rise in Hiron point, Char Ganga and Cox's Bazar, three tidal stations of Bangladesh, was 4.0 mm/year, 6.0 $\mathrm{mm} /$ year and $7.8 \mathrm{~mm} /$ year, respectively [11]. If the trend continues, sea water may intrude much longer distance in inland extending towards interior coast in low-laying areas of Bangladesh [12].

Being an agrarian country, $60 \%$ people of Bangladesh are directly or indirectly dependent on agriculture for their livelihood, with the contribution of $20 \%$ to its GDP [13]. The dominant land use in coastal Bangladesh is also agriculture. Even though gross and net-cropped areas in the coastal zone of Bangladesh are 144,085 and 83,416 hector, respectively [14], but net-cropped area of coastal zone has been showing a decreasing trend over the years due to a combination of factors. Gowing et al. [15] argued that coastal agri-lands often suffered from saline intrusion that prevented crop production in dry season.

CCC [10] study identified salinity intrusion as the most pressing problem for yield reduction in coastal agriculture. The study found that 830,000 million hectares of land at coastal Bangladesh were affected by soil salinity at different degrees. It is estimated that a net reduction of 0.5 million MT of rice production would take place due to a $0.3 \mathrm{~m}$ sea level rise in coastal areas of Bangladesh [16].

The rate of salinity intrusion in coastal Bangladesh is faster than it was predicted a decade ago [4]. Even though salinity intrusion is a slow process, but the impact is devastating. Based on observable symptoms, it is therefore assumed that agricultural lands in the coastal area will be affected by salinity; soil quality will be degraded which will eventually contribute to loss of agricultural production and thus threat food security [17]. NAPA (National Adaptation Programme of Action of Bangladesh) [18] has warned that the impact of saline water ingression in estuary and underground water is likely to be accelerated by sea level rise, land subsidence and low flow river condition. Different climate scenarios also indicate for a worrying future. World Bank [16] study predicted a $1 \mathrm{~m}$ sea level rise at the end of the century which might affect $17.5 \%$ of total land mass of the 
country. Miller [19] also warned that a sea level rise of $88 \mathrm{~cm}$ would flood agricultural lowlands and deltas in parts of Bangladesh. Both the scenarios implied that the future sea level rise would bring further land under inundation and therefore salinity would intrude to more inlands.

\section{Study Area}

Bangladesh is a part of the Bengal Basin, one of the largest geo-synclinals in the world. Comprising an area of $147,570 \mathrm{~km}^{2}$, the country has world's largest coastline of $710 \mathrm{~km}$, which lies along the Bay of Bengal. About $80 \%$ of the country's land is low-lying floodplains, half of which are subjected to tidal influence, formed through the sedimentation of three large rivers, the Ganges, the Brahmaputra and the Meghna.

The Himalayan range is located to the North and The Bay of Bengal to the South; where the southern coast converges at the northern tip of the Bay of Bengal, like a funnel towards the Meghna estuary. Such geo-physical settings along with abject poverty make the country vulnerable to climate change among which salinity intrusion is the most serious concern for coastal crop agriculture [20].

In Bangladesh, coastal areas are classified based on proximity to the sea and indicators like tidal movement, salinity and cyclone risk. Depending on the above stated parameter, 133 upazilas (upazila, formerly called thana, is a geographical region in Bangladesh used for administrative or other purposes) of 19 districts have been labeled as coastal upazila, encompassing a land area of $47,201 \mathrm{~km}^{2}$ (32\% of total area of the country).

Among the upazilas, 48 from 12 districts face the coast or lower estuary and known as exposed coast and the rest 99 upazilas those are behind the exposed coast are known as interior coast. Exposed coast have already met or crossed the threshold limit of the three parameters. While the interior coast met or cross the threshold limit of two indicators either like, tidal movement and salinity or any one of them, and are usually situated behind the exposed upazila and free from the risk of cyclone [21].

Based on geomorphologic characteristics, the coastal zone is divided into three distinct coastal regions, namely the western, central and eastern regions. The scope of this study was limited to the South-central coastal zone, situated between the eastern and western region, along the Meghna estuary. Most of the combined flow of the Ganges-Brahamputra-Meghna (GBM) system is discharged through the lower Meghna river estuary which is highly influenced by tidal interactions and consequential backwater effect [21].

The study was conducted at Panchkathi, Char Bhuinya and Kulchuri Patarchar village of Gosairhat Upazila under Shariatpur district. Among them Panchkathi and Char Bhuinya are under Nolmuri union (smallest local government unit) and the Kulchuri Patarchar is under Kuchaipotti union near the river Jayantia, a branch of the Meghna river (Figure 1). Gosairhat is located between $23^{\circ} 05^{\prime}$ and $23^{\circ} 10^{\prime}$ north latitude and between $90^{\circ} 20^{\prime}$ and $90^{\circ} 34^{\prime}$ east latitude on the western part of the lower Meghna River. The lower Meghna is one of the largest river systems in the world that conveys the combined flow of Ganges, Brahmaputra (Jamuna) and Meghna through the estuary to the Bay of Bengal. The quantity of discharged water through the lower Meghna to the Bay of Bengal is the 3rd highest around the world [22].

The District of Shariatpur, geographically known as interior coast, adjacent to the lower Meghna, already met the threshold limit of tidal movement and experienced some sorts of salinity in surface water during dry season and high tide. Withdrawal of water from upstream river system by dam and barrage and rising temperature, decreasing rainfall during dry season and sea level rise due to climate change, have a strong influence over fresh water distribution and tidal penetration which result in salinity intrusion. Salinity intrusion affects fresh water availability into the river systems and therefore, deteriorates usability of drinking and irrigation water. The lower Meghna is subjected to salinity intrusion mainly from decreasing fresh water flow in dry season and hence, saline water penetrates into the river. Generally, a mixture of fresh water and saline water prevails in an estuary. During the dry season, the saline water progresses towards landward more extensively, whereas, it is pushed out towards the bay in wet season. Fresh water input, depends on seasonality, largely has direct impact on salinity distribution along with water circulation and sediment exchange.

\section{Geomorphologic Characteristics of the Study Area}

The study area is located at the old Meghna estuarine flood plain that falls under the coverage of Agro Ecological Zone (AEZ) 19. The land elevation of the study area is medium high and medium low and the soil fall under Debiddar and Burichang category. The $\mathrm{pH}$ of Burichang soil class in a medium high land is ranging between 5.9 and 7.0. The organic matter content is medium, which is $2.3 \%$. The average content of Calcium, Magnesium, 


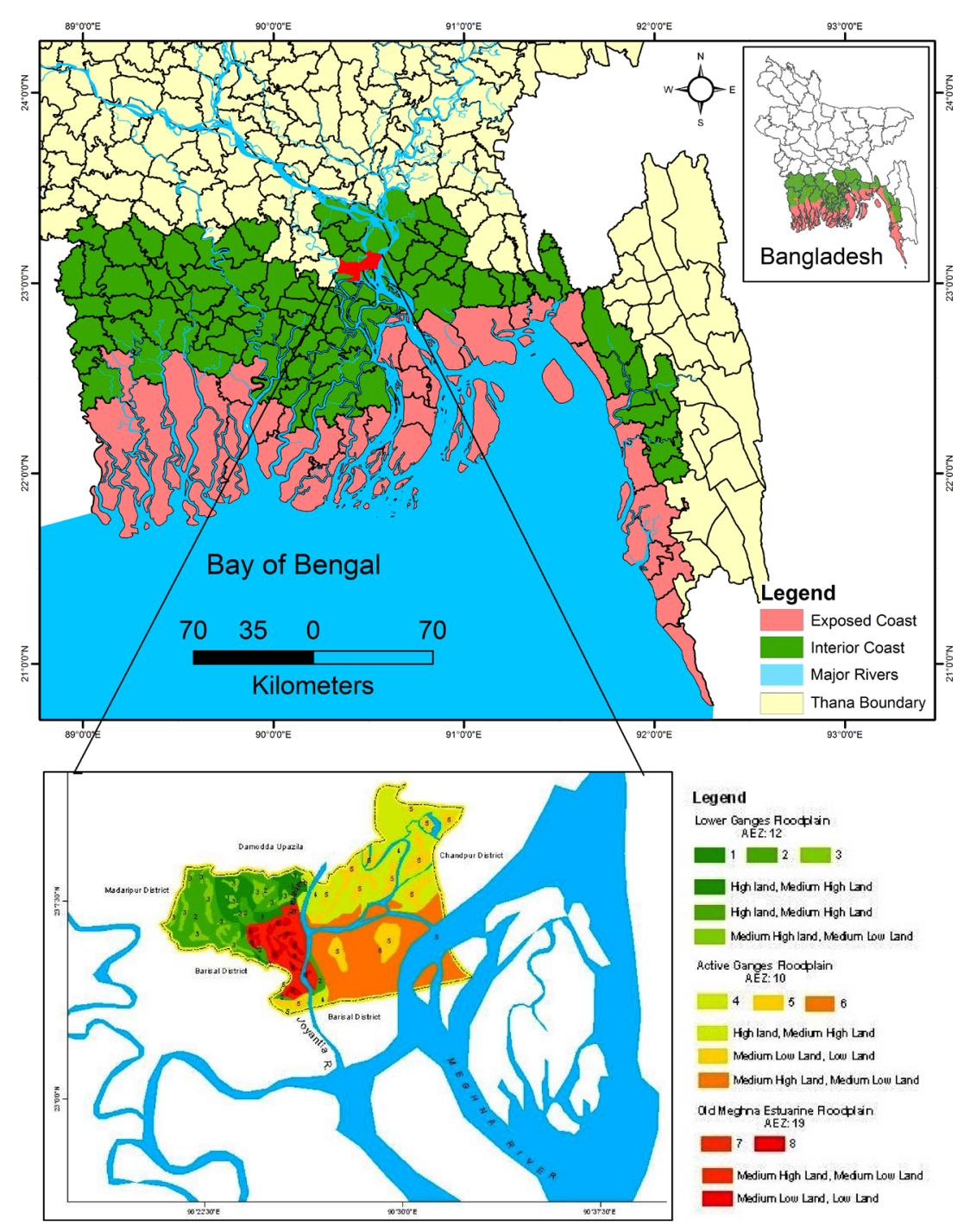

Figure 1. Map of the study area.

Copper, Iron and Manganese is higher, but Boron and Potassium content is low and Phosphorus content is extremely low [23]. ICZMP [21] estimates Gosiarhat's soil salinity as $4 \mathrm{dS} / \mathrm{m}$, surface water salinity as $5 \mathrm{dS} / \mathrm{m}$, ground water salinity as $2 \mathrm{dS} / \mathrm{m}$, and tidal fluctuation as $0.3 \mathrm{~m}$, that delineate upazila's status as the interior coast.

Salinity is increasingly considered as a hazard for the crop production in Gosairhatr upazila, particularly during dry season. The study, therefore, attempts to measure the salinity level, more specifically irrigation water salinity, and its impact on agricultural production. Salinity in river water has diversified impact on socioeconomic factors; however the study deals only with the impact of salinity on crop agriculture in the study area.

\section{Methodology}

The study has employed both qualitative and quantitative approaches to collect and analyze data. Both primary and secondary sources were used to collect data. Primary data were collected in between October and December 2011 through: testing of soil and water samples to measure salinity level, Focus Group Discussion (FGD), Key Informants Interviews (KII), household interviews, and personal observation. Secondary data were collected through assessing a number of scientific and policy studies. Review of secondary literature helps to identify the level of salinity in previous years in different coastal district in Bangladesh and what impacts it have laid on 
agriculture.

\subsection{Lab Test of Irrigation Water}

The study intended to explore the salinity level in surface water of the study area, which is mainly used for irrigating agriculture crops. Both physical and chemical properties of water were analyzed in the laboratory of Bangladesh University of Engineering and Technology (BUET). A total of 3 samples were collected, among them two were from the river Jayantia, a branch of the Meghna River, at in-point and out-point of Panchkathi village. The third one is collected from a water body derived from Jayantia River adjacent to Panchkathi village.

\subsection{Key Informant Interviews (KII)}

The key informants were selected based upon their expertise on the relevant subject matters required for analyzing the issue rigorously. For this study, four key informants interviews were conducted from public (BUET) and private (North South University) universities, GO (SRDI) and local NGO (SDS) respectively. Key informants were interviewed face to face and over telephone using semi-structured questionnaire. Apart from questionnaire, their comments were also taken into consideration.

\subsection{Focus Group Discussion (FGD)}

Using qualitative approach, one FGD was conducted comprising both men and women. Focus group helps to gather a wide range of information in a relatively short time. The participants of the FGD were selected using snowball sampling, comprised of 12 people including subsistence farmer, small landholders and sharecroppers. The rationale behind snowball sampling is to find people with a specific range of knowledge or skill. The participants were asked question regarding climate related hazards, livelihood, agricultural production, income generation, and food security and adaptation technique applied in the locality. The data collected from FGD were crossed checked by the interviewees from different households.

\subsection{Households Interview}

A total of 60 households were interviewed using a pre-tested semi-structured questionnaire to collect information of the farmers who are directly involved in crop production or indirectly involved in agriculture as wage laborer or other agri-activities. Questions were asked regarding impacts of salinity on crop yield, livelihood and health.

The samples were selected using a two-tier approach. In the first tier, firming community was identified with the help of local people and voter list collected from union office. Then, in the second tier, 60 households were selected using techniques of simple random sampling. Farmers in the study area grow different crops whose yield potential is different. However, to estimate the yield loss and decline in crop size, the respondents were asked common questions. Both farmers and wage laborers were asked the same questions regarding affect of salinity in agriculture.

Samples were taken only from three villages that had been used to construct a general scenario for the interior coast, more specifically Shariatpur district. Such small number of sample does not reflect the whole scenario of the interior coast or even the district, but the study could open a new window in climate change research for coastal Bangladesh which demands a more comprehensive study involving multidisciplinary approach.

\section{Causes of Salinity Intrusion}

Water circulation in the coastal zone is largely dependent on the factors like fresh water flow from the river, penetration of tide from the Bay of Bengal and the meteorological conditions like low pressure systems, cyclones, and storms surge and wind [22]. Both climatic and anthropogenic factors are responsible for causing salinity in the fresh water river (Figure 2). Climatic factors, albeit others, such as sea level rise is considered as the imperative cause of salinity in coastal areas [2].

\subsection{Climatic Factors}

Rising temperature and fluctuation in precipitation are considered as the drivers of climate change which are 


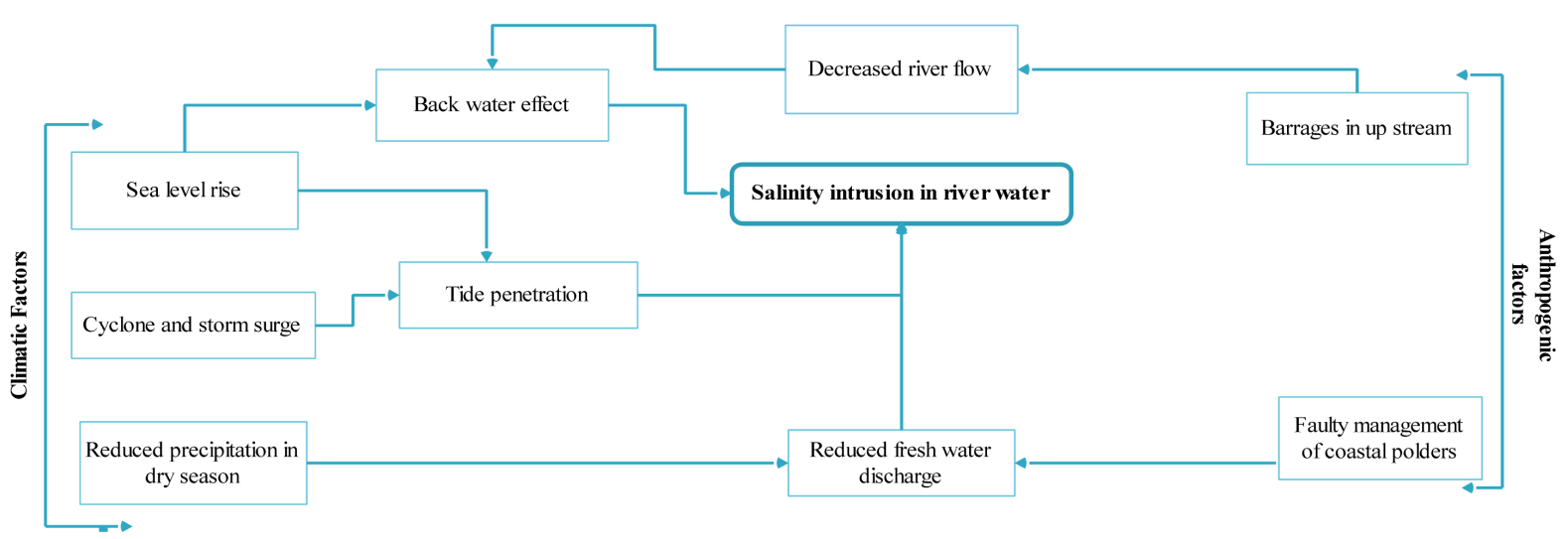

Figure 2. Causes of salinity intrusion in river water.

likely to have multiple impacts on the coastal zone of Bangladesh [12]. World Bank [16] study argued that increase in temperature in winter would be higher than that of summer and therefore, may cause higher rate of evaporation from the surface of the rivers. Moreover, due to climate change dry season precipitation would likely to decrease in near future. The cumulative impacts of both temperature rise and fluctuating precipitation would result in a low flow condition in the river. Thus, sea level rise will create a backwater effect in the mouth of the river and exacerbate salinity condition in the river water.

Precipitation pattern is likely to change in the South Asia due to higher temperature that results in stronger monsoon circulation [22]. Such fluctuation in precipitation causes flood with higher magnitude in wet season and reduces the availability of fresh water in dry season. Using Global Circulation Model (GCM), [4] showed that winter temperature is in a rising trend due to climate change. On the other hand, precipitation is likely to be increased throughout the summer monsoon. They argued that during summer air over the land gets warmer than the air over oceans which will create a further low pressure system in the land and exacerbate the monsoon. On the other hand, reduced precipitation and higher evaporation will create drier condition in winter [4].

Bangladesh is highly vulnerable to sea level rise [4]. UNEP [24] predicted a $1.5 \mathrm{~m}$ sea level rise by 2030 which will inundate $16 \%$ of total land mass and effect 15 million people, whereas [16] predicted a rise of $10 \mathrm{~cm}$, $25 \mathrm{~cm}$ and $1 \mathrm{~m}$ by the year 2020, 2050 and 2100 respectively which will likely to inundate $2 \%, 4 \%$ and $17.5 \%$ of total land mass respectively. Based on 22 years historical data, SMRC has developed a trend of sea level rise in three tidal stations in the coastal Bangladesh and the trend depicts a worrying picture where on an average coastal areas would experience $5.9 \mathrm{~mm}$ sea level rise every year [11].

Sea level rise has direct influence on salinity intrusion in landward. Shamsuddoha and Chowdhury [25] predicted that a rise of $88 \mathrm{~cm}$ of sea level would penetrate $5 \mathrm{ppt}$ saline front into $40 \mathrm{~km}$ inland at the fresh water pocket of the Tetulia River in Meghna estuary. Penetration of tidal water will exacerbate during dry season when the fresh water flow from river recedes. Miah [26] also assessed distribution of salinity level and landward intrusion in the rivers and surface water for the base year 2005 using the Southwest region model and Bay of Bengal model for dry and monsoon season. The study [26] found that in monsoon (June to September), the saline water is fully flushed out of the Meghna Estuary, but in dry season (December to March) deep landward intrusion occurs through various inlets in the Western part of coastal zone and through Meghna Estuary. The study concluded that salinity will intrude more landward specially during dry season due to sea level rise and consequently brackish water area would increase and it is seen that sea level rise of $27 \mathrm{~cm}$ causes $6 \%$ increase of brackish water area compared to base condition [26].

The coastal zone and offshore island in Bangladesh are very flat with height less than $3 \mathrm{~m}$ above the Mean Sea Level (MSL). The astronomical tide, therefore, with higher range penetrates landward very frequently. Moreover, intensity and frequency of tropical cyclone and associated storm surge has increased many folds recently due to climate change [12]. Khan et al. [27] predicted that climate change would increase the frequency of tropical cyclones with larger peak wind speeds and heavier rainfall. Karim and Mimura [12] developed eight scenarios on coastal flooding based on present climatic condition and showed that for a storm surge under $21^{\circ} \mathrm{C}$ SST rise and $0.3 \mathrm{~m} \mathrm{SLR}$, flood risk area would be $15.3 \%$ greater than the present risk area and depth of flooding would increase by as much as $22.7 \%$ within $20 \mathrm{~km}$ from the coastline. 
Another natural factor of increasing salinity at coastline is back water effect that takes place at the mouth of the river when fresh water is not sufficient enough to counterpart tide water moving towards river from sea. Ali [28] identified different causes of backwater effect, among them i) Southwest monsoon wind; ii) astronomical tides; iii) storm surge are responsible for backwater effect at the mouth of the Meghna estuary. With the swell of present sea level, river-sea water gradient will decrease which would create retardation of discharge and cause saline water to penetrate inward.

\subsection{Anthropogenic Factors}

Bangladesh is formed at the confluence of the three mighty rivers: Ganges, Brahmaputra and Meghna (GBM). The basins of three river systems with an area of 1.6 million $\mathrm{km}^{2}$ passing through India, China, Nepal, Bhutan and Bangladesh, drain to the Bay of Bengal through the Meghna estuary. Different types of anthropogenic interventions in the form of dam, barrage, and water diversion channel are established on these river basins by the sharing countries. Thus water withdrawal or diversion of river water at upstream creates a low flow condition in the downstream during the dry season. Alongside faulty management of coastal polders also accelerates inland salinity ingression.

The highest contributor of fresh water to the lower Meghna is the Padma River, the combined flow of Ganges and Brahmaputra (Jamuna), which provides $90 \%$ of total fresh water [22]. However, water flow of the Ganges River is largely controlled by the Farakka Barrage. Mirza [29] observed a notable change in the hydrology of the Ganges River at the post Farakka period. It is estimated that water flow has been has been dropped to a minimum $150 \mathrm{~m}^{3} / \mathrm{s}$ at the Hardinge bridge point in 1995 from 20,000 $\mathrm{m}^{3} / \mathrm{s}$, which was the average minimum flow of the Ganges during the pre-Farakka period [29]. Mirza [29] found that at the post-Farakka the discharge during monsoon (July-October) increased whereas decreased significantly during the dry season (November-May). Increased flow in the monsoon might have contributed to exacerbate the flooding condition, but decreased flow has been aggravating salinity intrusion in the interior coast. During wet season fresh water contribution from the upper Meghna to the lower Meghna is only 10\%, trivial amount compare to the flow of the Ganges and the Brahmaputra [22]. Nevertheless, the flow of the upper Meghna is also partially regulated by another barrage built on the Barak River in its upstream.

Coastal polders were built to prevent tidal intrusion aiming to boost agricultural production. However, [30] found that many polders were damaged due to undesirable breaching to promote shrimp culture that eventually resulted in saline water ingression in the productive agri-lands. Water logging in the sluice gates of polders or dikes is another problem that likely to increase salinity in the coastal zone. Karim and Mimura [12] noticed that exit points of polders were blocked in Western coastal zone because of riverbed rise through silt deposition, resulting in the areas into permanent water logged. They further reported that the water logging has extended to $1500 \mathrm{Km}^{2}$ Ganges tidal flood plain that was previously used for agriculture [12].

\section{Results and Discussion}

\subsection{Level of Salinity in Irrigation Water}

Salinity in aquatic ecosystem is determined by the total amount of dissolved salts present in it. Four types of cations prevail in saline water such as Sodium $\left(\mathrm{Na}^{+}\right)$, Potassium $\left(\mathrm{K}^{+}\right)$, Calcium $\left(\mathrm{Ca}^{++}\right)$and Magnesium $\left(\mathrm{Mg}^{++}\right)$and 3 anions such as Chloride $\left(\mathrm{Cl}^{-}\right)$, Carbonate $\left(\mathrm{CO}_{3}^{-}\right)$or Bi-Carbonate $\left(\mathrm{HCO}_{3}^{-}\right)$and Sulphate $\left(\mathrm{SO}_{4}^{-}\right)$. However, the most common and plentiful ions present in saline water are $\mathrm{Na}^{+}$and $\mathrm{Cl}^{-}$. Salinity of an aqueous system can be measured by determining concentration of salt in water. Two most common ways to measure salinity are: a) Total Dissolved Solids (TDS) ${ }^{1}$, b) Electrical Conductivity (EC) ${ }^{2}$.

This study measured EC of irrigation water samples to determine salinity level. The salinity has been measured in micro Siemens per $\mathrm{cm}(\mu \mathrm{S} / \mathrm{cm})$ at $25^{\circ} \mathrm{C}$. The EC of irrigation water in the study area was found as 1305 $\mu \mathrm{S} / \mathrm{cm}$ or $0.72 \mathrm{ppt}$ at $25^{\circ} \mathrm{C}$. On the other hand soil salinity in the study area has been measured as $<4 \mathrm{dS} / \mathrm{m}[21]$.

\footnotetext{
${ }^{1}$ Total Dissolved Salt (TDS) is often used to determine water salinity. It is estimated by evaporating a known volume of water and then estimating the weight of the solid waste residue. Total dissolved solids are measured in the laboratory and are typically recorded in mg/L.

${ }^{2}$ Electrical Conductivity (EC) is the easiest and the most common method of measuring salinity. It is estimated by passing electrical current between two electrodes in the water solution and measuring how readily the current flows between the plates. An electrical current flows through the water due to this voltage and is proportional to the concentration of dissolved salts in the water. The more salts in water the more conductive the solution is, resulting a higher electrical conductivity. $\mathrm{EC}$ is usually expressed in micro Siemens per $\mathrm{cm}$ at $25^{\circ} \mathrm{C}(\mu \mathrm{S} / \mathrm{cm})$.
} 
This study considered soil salinity of the study area as $3.5 \mathrm{dS} / \mathrm{m}$ (approximately) to calculate the yield potentiality of crops.

\subsection{Effects of Salinity in the River Water}

Salinity intrusion in river water may cause economic loss in terms of crop yield reduction, hampering industrial production, increasing health hazard and reducing productivity of the forest species [20]. Agriculture production is likely to decrease as saline containing water reduces plant growth through concentrating salt in the root zone of plant and resulting in nutrients imbalance and yield loss. Industrial production is reduced when saline water from river is used to cool condenser or to keep turbine running. Saline water causes leakages in equipment and makes production loss and also increases production cost by compelling the producer to import fresh water for avoiding the corrosion and leakage. For instance, Pakshi paper mill closed down during 1993 due to salinity intrusion in the north of Khulna [29]. Increase of salinity in the adjacent river channels hampers growth of the tree species. Reduction in fresh water and salinity intrusion along with soil quality depletion slow down plant growth and reduce productivity that put adverse effect on biodiversity and wild life.

River water with high level of salinity, when used for drinking purpose, may have numerous impacts on human health and livestock. Khan et al. [27] argued that drinking highly saline water might cause an increased rate of preeclampsia and gestational hypertension in pregnant women. SRTT [31] report stated that salinity in drinking water might have a connection with kidney diseases like kidney stone and Rheumatism. The report further opined that salinity has negative impacts on domestic cattle in terms of deterioration of the milk productivity and reproductive health [31].

\section{Impact of Salinity on Agriculture Crops}

Salinity affected irrigation water has profound impact on crop production (Figure 3). Bauder et al. [32] stated that the impact of irrigation water on crop production depends upon the presence of salient factors: salinity or concentration of total dissolved salts; disproportion of $\mathrm{Na}^{+}$with other cations like $\mathrm{Ca}^{++}$and $\mathrm{Mg}^{++}$; alkalinity or presence of excessive $\mathrm{CO}_{3}^{-}$or $\mathrm{HCO}_{3}^{-}$more than the desired level; $\mathrm{pH}$; excessive presence of toxic ions like $\mathrm{Na}^{+}$and $\mathrm{Cl}^{-}$.

To investigate suitability of irrigation water of the study area, parameters of the samples were then compared with standard level as set by US based soil conditioners supplier Soil First Consulting [33]. The result shows that some of the parameters such as $\mathrm{pH}$, alkalinity and chloride already exceed the desired level (Table 1). The value of salinity though lower than the desired level, however, present concentration may have significant impact on crop production when the soil of irrigated land has already been affected by salinity.

1) Osmotic effect

The most common response of plant towards salinity is reduction in growth. In low to moderate concentration, salinity affects crop production by lowering the soil-water potential and increases concentration of salt at the root zone. Low water potential indicates that plant cannot extract sufficient amount of water from soil and maintain turgor at very low soil-water condition. This effect is known as osmotic effect. Bauder et al. [32] argued that yield of a crop is directly linked to the quantity of water passed through it by water transpiration. When EC gets higher, less water is likely available to plants. Yield potential of plants, therefore, gets deteriorated with the increase of EC in irrigation water.

Table 1. Irrigation water parameters in the study area.

\begin{tabular}{ccc}
\hline Parameter & Standard level [33] & $\begin{array}{c}\text { Present level } \\
\text { (in the study area from the empirical study) }\end{array}$ \\
\hline $\mathrm{pH}$ & $\begin{array}{c}5.5-6.0 \text { is the ideal condition for both } \\
\text { irrigation and tank mixing; }>7.0 \text { can cause } \\
\text { problems, especially in tank mixing }\end{array}$ & 7.99 \\
Salinity or concentration of salt & $1.5 \mathrm{dS} / \mathrm{m}$ & $1.305 \mathrm{dS} / \mathrm{m}$ \\
Alkalinity (carbonate) & $<50 \mathrm{ppm}$ & $221 \mathrm{ppm}$ \\
Chloride ion & $<140 \mathrm{ppm}$ & $500 \mathrm{ppm}$ \\
Sodium ion & $0-50 \mathrm{ppm}$ & - \\
\hline
\end{tabular}




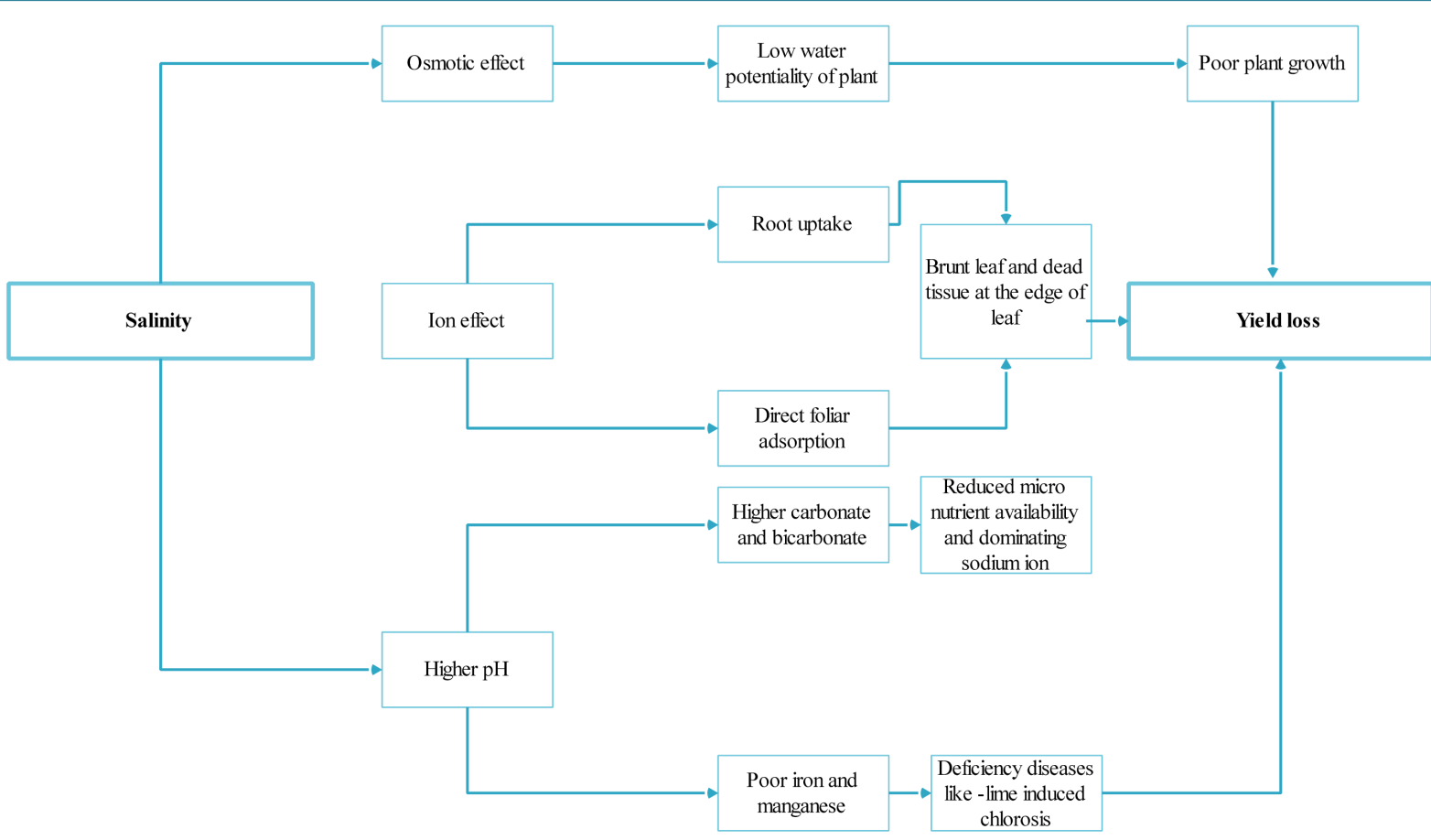

Figure 3. Impact of salinity on agriculture crop.

The current study has found that EC of the irrigation water is $1.305 \mathrm{dS} / \mathrm{m}$ which is slightly saline according to FAO (1992) guideline and moderately saline according to FAO (1976) guideline, whereas highly saline according to USDA (1954), cited in [34] (Table 2).

2) Ion effect

Excessive presence of ions like $\mathrm{Na}$ and $\mathrm{Cl}$ in irrigation water may cause toxic effects in plant growth. The toxic effects caused by specific ions may occur either when the ions are taken up by the root or when gets the direct contact with the leaves.

Even though $\mathrm{Cl}$ is an essential element for plant growth, but higher concentration may restrain plant growth or cause toxicity to some plants. Irrigation water with high $\mathrm{Cl}$ content is likely to reduce the availability of phosphorus to plants. Higher concentration of $\mathrm{Cl}$ ions also causes leaf tip burn, disruption of membrane function, obstruction in internal solute balance that hampers nutrient uptake [35]. In the study area, $\mathrm{Cl}$ ion concentration in irrigation water was measured as $500 \mathrm{ppm}$, which implies that crops in the study area are susceptible to every possible effect of higher $\mathrm{Cl}$ concentration as argued by Bauder et al. [32].

3) Direct foliar adsorption

Some plants may not be responsive to root uptake of toxic ions like $\mathrm{Na}$ or $\mathrm{Cl}$ ion, however may be sensitive and build up symptoms when come in contact directly with the ions. The toxicity of $\mathrm{Cl}$ ions and $\mathrm{Na}$ ions due to adsorption is visible when irrigation is carried through sprinkler method. This toxic effect causes foliar damage of some specific crops in terms of scalding or burning the leaves coming in contact with the specific ions. Damage caused by direct contacts of ions gets more severe when irrigation takes place in a hot and dry weather [35].

The current study found that the $\mathrm{Cl}$ ion content in irrigation water is much higher than the desired level. Even though Na ion concentration of irrigation water in the study area has not been estimated under the current study, it can be predicted that the concentration of $\mathrm{Na}$ ion would also be higher as that of $\mathrm{Cl}$ ion is higher. The farmers of the study area claimed that they have been experiencing some of the impacts of salinity such as early yellowing of leaves, burning leave tip, early aging of plant which might create dropping down of leaves in premature stage and therefore, reduce the rate of photosynthesis.

4) $\mathrm{pH}$, alkalinity and nutrient deficiency

Bauder et al. [32] recommended that ideal $\mathrm{pH}$ range for irrigation water is 6.5 - 8.4 and warned that $\mathrm{pH}$ above 8.5 might accelerate corrosion of irrigation system. High concentration of $\mathrm{CO}_{3}$ and $\mathrm{HCO}_{3}$ ions make water alkaline and increase $\mathrm{pH}$ value in irrigation water which makes minerals insoluble with $\mathrm{Ca}$ and $\mathrm{Mg}$ ions leaving $\mathrm{Na}$ 
Table 2. Classification of irrigation water based on electrical conductivity (EC) [34].

\begin{tabular}{|c|c|c|c|}
\hline \multicolumn{4}{|c|}{$\mathrm{EC}$ of water in $\mathrm{dS} / \mathrm{m}(=\mathrm{mS} / \mathrm{cm})$} \\
\hline Classification & USDA (1954) & FAO (1976) & FAO (1992) \\
\hline Non-saline & $<0.25$ & $<0.75$ & $<0.7$ \\
\hline Slightly saline & & & $0.7-2.0$ \\
\hline Moderately saline & $0.25-0.75$ & $0.75-3.0$ & $2-10$ \\
\hline Highly saline & $0.75-2.25$ & $>3.0$ & $10-25$ \\
\hline Very high saline & $2.25-50$ & & $25-45$ \\
\hline Sea water: $>45 \mathrm{dS} / \mathrm{m}$ & & & \\
\hline
\end{tabular}

ions as the dominant in the solution. Higher alkalinity in irrigation water reduces micro nutrient availability as well [36]. For Instance, "Lime Induced Chlorosis" may arise by high $\mathrm{pH}$ with the symptom of yellow-white leaves on plants [37].

The study measured $\mathrm{pH}$ level as 7.99 and concentration of $\mathrm{CO}_{3}$ ion as $221 \mathrm{ppm}$, which is much higher than the desired level. Higher concentration of $\mathrm{CO}_{3}$ ion in irrigation water results in increased concentration of $\mathrm{Na}$ ions in the root zone. Photosynthesis, thereby, may be hampered if $\mathrm{Na}$ ion concentrates in the stomata of leaves.

\subsection{Farmer's Perception on the Impact of Salinity on Crop Yield}

Agriculture is the main source of livelihood for people of Gosairhat upazila. Among the interviewee households, sharecropper appeared as the highest number and most of them grow Boro rice in dry season. They also grow wheat, some tuber crops, vegetables, pulses, oil seeds and spices in dry season.

Local people's perception reveals that salinity intrusion is an increasing hazard to agriculture in dry season. Among the respondents, $72 \%$ opined that salinity has become the most prevalent hazard for their crop production during the dry season. Even they could test saline in their drinking water collected from shallow tube wells. They argued that crop production has been declining for last 5 - 6 years. Majority of the respondents (78\%) agreed that salinity intruded to their land when they used water from their adjacent rivers such as the lower Meghna and Jayantia River during high tide. However, 8\% respondents believed that manmade hazards like emission from brickfield could have significant impacts on the reduction of crop yield in their locality. Water scarcity was identified as hazard by $4 \%$ of the respondents and argued that they have been facing fresh water crisis both for drinking and irrigation because of the presence of salinity.

The result shows that impact of salinity on crop production is visible in the study area. Most of the respondents (92\%) in the study area claimed that they have been experiencing yield reduction (Figure 4). Moreover, some of the respondents (42\%) added decline in crop size as an impact of salinity increase. Some respondents reported that burning leaf tip and early yellowing of leaf have increased recently. A small number of respondents reported that they have changed the crop variety to cope up with increasing salinity (Figure 4).

The most pressing problem faced by the farmers in the study area is yield loss. However, the yield loss is not uniform for all food crops.

\subsection{Impact of Salinity on Potential Yield}

Different crops respond to salinity differently even at a same level. Based on yield potentiality, [38] sets the threshold value for different crops in response to salinity. The higher the threshold value, the more a crop is tolerant to salt. Table 3 presents threshold value of different winter vegetables and the corresponding percent yield loss [38]. The yield potentiality of crops is calculated on the basis of per unit increase of soil salinity (EC in $\mathrm{dS} / \mathrm{m}$ ) from their threshold value. To calculate the yield potentiality, the current study has considered soil salinity at root zone as $3.5 \mathrm{dS} / \mathrm{m}$ based upon [21] study where they estimated soil salinity for the studied upazila below $4 \mathrm{dS} / \mathrm{m}$.

By calculating the yield potentiality of different winter crops in the study area and comparing them with that of the standard yield potentiality as proposed by [39], it has been found that there is small decline of yield 


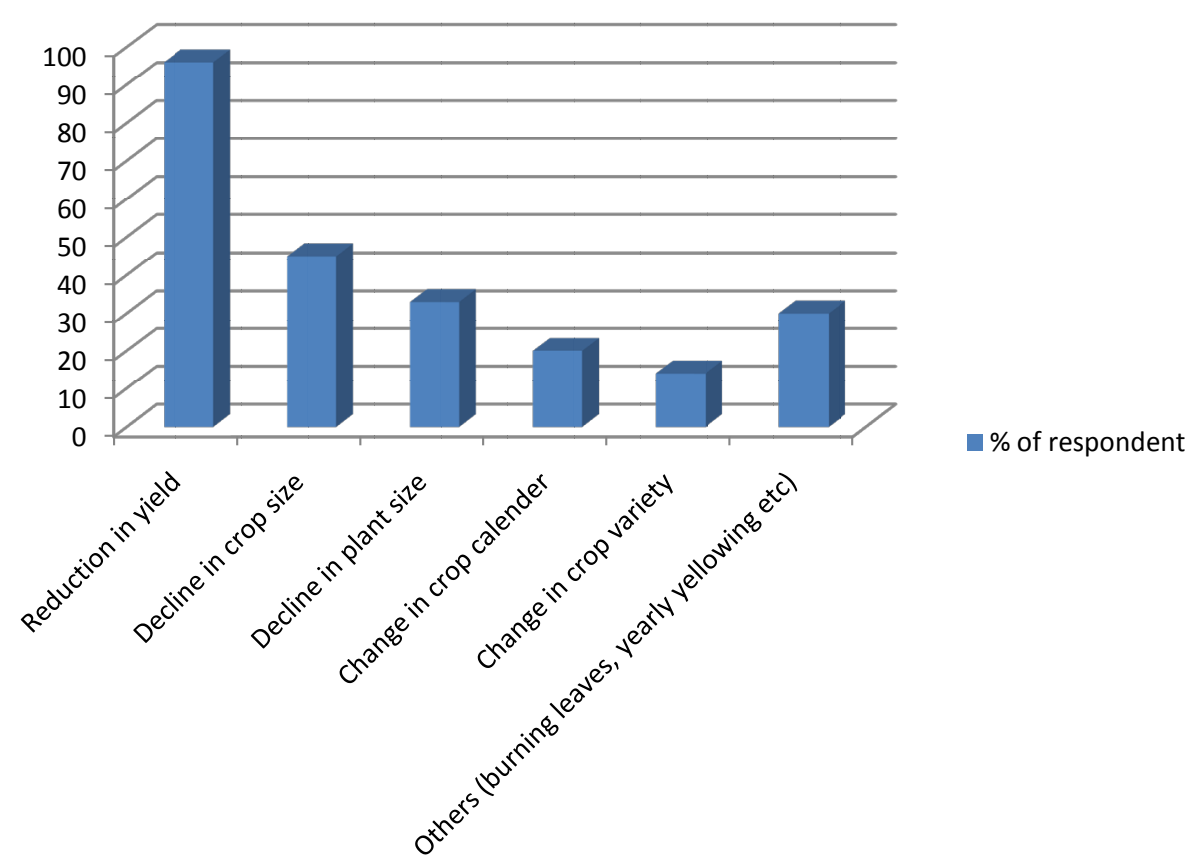

Figure 4. Local farmers’ perception on the impact of salinity on crop production.

Table 3. Potential yield reduction due to different soil salinity.

\begin{tabular}{|c|c|c|c|c|c|}
\hline \multirow{2}{*}{ Crop } & \multicolumn{3}{|c|}{$\begin{array}{l}\text { \% in yield reduction based on different soil } \\
\text { salinity (EC in } \mathrm{dS} / \mathrm{m})[38]\end{array}$} & \multirow{2}{*}{$\begin{array}{c}\text { Yield potential (\%) } \\
\text { proposed by [39] } \\
0 \%\end{array}$} & \multirow{2}{*}{$\begin{array}{c}\text { Yield potential (\%) } \\
\text { measured for field crops } \\
3.5 \%\end{array}$} \\
\hline & $0 \%$ & $10 \%$ & $25 \%$ & & \\
\hline Onion & 1.2 & 1.8 & 2.8 & 72 & 66.67 \\
\hline Beans & 1.0 & 1.5 & 2.3 & 66.67 & --- \\
\hline Potato & 1.7 & 2.5 & 3.8 & 80.56 & 77.78 \\
\hline Sweet potato & 1.5 & 2.4 & 3.8 & 79.2 & 78.57 \\
\hline Carrot & 1.0 & 1.7 & 2.8 & 70.58 & \\
\hline Radish & 1.2 & 2.0 & 3.1 & 74.7 & 74.04 \\
\hline Pepper & 1.5 & 2.2 & 3.3 & --- & ---- \\
\hline
\end{tabular}

The formula of yield potentiality was developed by Grattan (2002) that has been applied to estimate the yield potentiality in this study. The formula is $\%$ yield $=100-b(E C e-a)$ [Where $a=$ threshold limit, $b=$ percent of yield loss with the increase in one unit of salinity above the threshold limit, ECe: Average soil salinity in the root zone]. Threshold value is the value of soil salinity level at which plants start experiencing the impact of salinity in terms of yield loss.

potentiality in the study area compared to the standard yield potentiality (Table 3). This is because, apart from the salinity hazard, cold wave, pest invasion and industrial pollution also might have influence on crop yield. In addition, effect of soil salinity may also differ depending on the factors like type of the soil, slope of the field, method of irrigation, management of salinity, timing of irrigation, fertilizer and manure practice. These factors might have also played important roles in crop yield.

The study finds that the vegetable crops are more sensitive to the present level of salinity than the cereal crop (Table 4). Both high yielding hybrid and local variety are produced in the study area, but local varieties seemed more likely to have yield reduction than the high yielding hybrid variety. Amacher et al. [40] found that fruits, vegetables and ornamental crops are more sensitive to salt than cereal crop. This study has also observed similar trend. High yielding variety of rice and wheat are practiced in the dry season and these crops are likely to be less sensitive to the present level of salinity. However, local variety of cereal crops is more responsive to present level of salinity and showing a declining trend in production. Effects of soil salinity differ depending on the 
Table 4. Yield loss of different winter crops (parentheses shows frequency of respondent).

\begin{tabular}{|c|c|c|c|c|c|}
\hline \multirow{2}{*}{$\begin{array}{l}\text { Crop } \\
\text { Boro }\end{array}$} & \multicolumn{4}{|c|}{ Yield loss (kg/decimal) } & \multirow{2}{*}{$\begin{array}{c}\text { No loss } \\
(29)\end{array}$} \\
\hline & $1(12)$ & $2(15)$ & $5(4)$ & ---- & \\
\hline Wheat & $2(18)$ & $5(10)$ & --- & ---- & $(32)$ \\
\hline Potato & $4(12)$ & $5(15)$ & $8(7)$ & $10(21)$ & (5) \\
\hline Mustard seed & $2(19)$ & $4(10)$ & $5(25)$ & ---- & (6) \\
\hline Sweet potato & $3(17)$ & $4(14)$ & $6(3)$ & $7.5(21)$ & (5) \\
\hline Amaranth & $1(25)$ & $2(19)$ & --- & --- & (16) \\
\hline Lentil & $2(14)$ & $3(9)$ & $4(18)$ & $6(7)$ & $(12)$ \\
\hline Radish & $3(12)$ & $5(15)$ & $7(26)$ & ---- & (7) \\
\hline Chili & $2(12)$ & 3 (19) & $5(14)$ & $6(8)$ & (7) \\
\hline Onion & $2(10)$ & $2.5(19)$ & $4(22)$ & --- & (9) \\
\hline Grass pea & $3(15)$ & $5(18)$ & $6(10)$ & ---- & $(17)$ \\
\hline
\end{tabular}

factors like type of the soil, slope of the field, method of irrigation, management of salinity, timing of irrigation, fertilizer and manure practice.

\subsection{Managing Salinity Problem}

Moderate to low level of salinity could be managed through leaching process either naturally or artificially. Naturally, rainfall contributes to leach salt from soil surface but in dry season, when rainfall is insufficient, the artificial process or irrigation should be applied. To manage salinity, more water needs to be applied other than regular water requirement of the crop. However, there is a high risk of increasing salinity content at root zone in case of irrigation with saline contaminated water. Deep-water irrigation is required in case of high concentration of salinity in root zone. If soil salinity is too high comparing to the desired level of a certain vegetable in its root zone and the root is $30 \mathrm{~cm}$ depth, $15 \mathrm{~cm}$ of water is capable of leaching salinity by $50 \%$ and $30 \mathrm{~cm}$ of water is capable of leaching salinity by $80 \%$ and $60 \mathrm{~cm}$ by approximately $90 \%$ [39].

Irrigation method and adequate drainage also influence soil salinity. Irrigation water, containing various dissolved minerals, has a great influence on crop production as well as on soil salinity management. Nevertheless, minerals or salts and their concentration as well as composition vary largely depending on the source of irrigation water. Simple surface water run-off cannot leach soil salinity; rather water should be drained through soil. Therefore, deep tillage is required to ensure internal drainage as it is very important to break up the restraining layer that delays water movement. In this regard, sprinkler irrigation provides a better control of water application rates. In plain land flood irrigation can also be used as an effective tool for controlling salinity.

Surface water is the principal source of irrigation water in the study area. EC of the irrigation water in the study area has been estimated as $1.3 \mathrm{dS} / \mathrm{m}$, leaching is highly recommended for the study area especially during winter. To calculate the leaching requirement for different winter crops, FAO [38] developed following equation which is applied in the study:

$$
\mathrm{LR}=\mathrm{ECw} / 5(\mathrm{ECe})-\mathrm{ECw}
$$

[In Equation (1), LR = the minimum leaching requirement needed to control salts within the tolerance (ECe) of the crop with the ordinary surface method of irrigation, $\mathrm{ECw}=$ Salinity of the applied irrigation water in $\mathrm{dS} / \mathrm{m}$ and ECe = average soil salinity tolerated by the crop as measured on a soil saturation extract.]

Leaching fraction is a percentage of water that needs to be applied in the field so that it can drain the root zone $^{3}$. Applying the Equation (1), leaching requirement of some major winter crops of the study area are estimated (Table 5).

Leaching requirement of different crops varies according to their threshold limit as well as percent of yield that a producer desires. The more percent of yield a producer desires, the more leaching is required. Therefore,

\footnotetext{
${ }^{3}$ Leaching fraction of $1 / 10$ or 10 percent indicates that if 1 acre-foot of water is applied in 1 acre of land, the water drains below the root zone is 0.1 acre-foot [39].
} 
Table 5. Leaching requirement for different winter crops in the study area.

\begin{tabular}{ccc}
\hline Crop & Leaching requirements for $100 \%$ yield potential & Leaching requirements for $90 \%$ yield potential \\
\hline Onion & 0.27 & 0.168 \\
Beans & 0.35 & 0.20 \\
Potato & 0.18 & 0.116 \\
Sweet potato & 0.209 & 0.12 \\
Carrot & 0.35 & 0.18 \\
Radish & 0.27 & 0.149 \\
\hline
\end{tabular}

Grattan (2002) defined the leaching process as "Leaching is the process of applying more water to the field than can be held by the soil in the crop root zone such that the excess water drains below the root system, carrying salts in it."

salt tolerance values of different crops of a certain geographic area should be used as a guide for the farmer to choose what crop they should produce to have the optimal production considering physical condition of an area. In the study area, neither the agricultural office nor the farmers are informed about the salt tolerance limit nor do they have any chart.

\section{Conclusions}

The exposed coast and some areas of the interior coast in Bangladesh have already exceeded the threshold limit of tidal movement and salinity intrusion [21]. Even though, Gosairhat upazila, an interior coast, has already crossed the threshold value of tidal fluctuation, yet below the threshold limit of salinity intrusion. However, the salinity levels both in soil and surface water in the area show an increasing trend. Climate change has been accelerating the salinization process through sea level rise and increased evaporation resulting from higher temperature. Rising sea level is likely to penetrate more seawater to inland and bring more area under the coverage of tide infiltration. Cyclone and storm surge will also increase the height of tidewater onto the river. Consequently, concentration of salinity in river water is also likely to be increased.

The study area experiences salinity due to tidewater movements in different canals of the lower Meghna that crosses the upazila. Moreover, higher rate of evaporation from soil also contributes to increasing salt concentration in soil. Therefore, salinity problem becomes acute in hot and dry season than that of wet season. Furthermore, a trend of decreasing rainfall in winter has already been predicted [16], which will hinder natural leaching process of soil salinity.

Present salinity concentration has already put a threat to the crop production and a significant yield loss has already been observed in the dry season. In the changing scenario of the sea level rise, it has been predicted that increasing concentration of salinity will create more pressure to the farmer by reducing yield which will ultimately affect livelihood, income generation and food security.

Leaching and irrigation time are considered as useful tools for managing low to moderate level salinity. Crops with a higher threshold value are likely to have lower leaching requirements and therefore, will require a less amount of irrigation water. On the contrary, low tolerance value requires high leaching that means more water is needed to increase the yield potentiality which will incur high production cost. Moreover, salinity in irrigation water also influences the soil salinity and $\mathrm{pH}$. Higher $\mathrm{pH}$ in soil is likely to create a deficiency of nutrient like phosphorus, iron etc. To reclaim the nutrients, appropriate fertilizer should be applied against the deficiency of certain nutrient. For instance, to address the deficiency disease named "Lime-induced Chlorosis", an Iron deficiency disease, Iron sulphate needs to be applied in the soil [36]. High pH due to high salinity usually causes $\mathrm{CO}_{3}$ and $\mathrm{HCO}_{3}$ salt to be insoluble and therefore, creates $\mathrm{Ca}$ and $\mathrm{Mg}$ ions deficiency with the dominance of $\mathrm{Na}$ ion. To address the problem, gypsum or calcium sulphate could be applied to release Ca ion and replaces Na ion [36]. Timing of irrigation is another important factor in managing salinity. A dry and hot day is likely to evaporate more water from soil and therefore, cause more salt to be concentrated in the plant root zone. Therefore, for irrigation, a cool and humid weather or night is preferable. The frequency of irrigation should be increased in case of a hot and dry weather to address salinity stress. 


\section{Acknowledgements}

This study was conducted under RESOLVE project, jointly implemented by Unnayan Onneshan and Oxfam Novib. The Authors wish to thank Dr. Rashed Al Mahmud Titumir for his scholarly and mental support throughout the study and preparing the manuscript. Also thanks to SDS (Shariatpur Development Society) for their immense logistic and technical support during field data collection. A draft version of the preliminary study report was uploaded in the Unnayan Onneshan website (www.unnayan.org) for comment.

\section{References}

[1] Nicholls, R.J., Wong, P.P., Burkett, V.R., Codignotto, J.O., Hay, J.E., McLean, R.F., Ragoonaden, S. and Woodroffe, C.D. (2007) Coastal Systems and Low-Lying Areas. In: Parry, M.L., Canziani, O.F., Palutikof, J.P., van der Linden, P.J. and Hanson, C.E., Eds., Climate Change 2007: Impacts, Adaptation and Vulnerability. Contribution of Working Group II to the Fourth Assessment Report of the Intergovernmental Panel on Climate Change, Cambridge University Press, Cambridge, 315-356.

[2] IPCC AR4 (2007) Intergovernmental Panel on Climate Change (IPCC), Climate Change: 2007 Synthesis Report.

[3] German Watch (2004) Sea Level Rise in Bangladesh and the Netherlands: One Phenomenon, Many Consequences. http://www.germanwatch.org/download/klak/fb-ms-e.pdf

[4] Agrawala, S., Ota, T., Ahmed, A.U., Smith, J. and Aalst, M.V. (2003) Development and Climate Change in Bangladesh: Focus on Coastal Flooding and the Sunderbans. Organization for Economic Co-Operation and Development (OECD). http://www.oecd.org/dataoecd/46/55/21055658.pdf

[5] Haider, R. (1992) Cyclone 91’ Revisited. Bangladesh Center for Advanced Studies, Dhaka.

[6] Rashid, M.M., Hoque, A.K.F. and Iftekhar, M.S. (2004) Salt Tolerances of Some Multipurpose Tree Species as Determined by Seed Germination. Journal of Biological Sciences, 4, 288-292. http://dx.doi.org/10.3923/jbs.2004.288.292

[7] Ashraf, M.Y., Sarwar, G., Ashraf, M., Afaf, R. and Sattar, A. (2002) Salinity Induced Changes in $\alpha$-Amylase Activity during Germination and Early Cotton Seedling Growth. Biologia Plantarum, 45, 589-591. http://dx.doi.org/10.1023/A:1022338900818

[8] Shahid, S. (2010) Impact of Climate Change on Irrigation Water Demand of Dry Season Boro Rice in Northwest Bangladesh. Climatic Change, 105, 433-453. http://dx.doi.org/10.1007/s10584-010-9895-5

[9] Yadav, J.S.P., Sen, H.S. and Bandyopadhyay, B.K. (2009) Coastal Soils-Management for Higher Agricultural Productivity and Livelihood Security with Special Reference to India. Journal of Soil Salinity \& Water Quality, 1, 1-13.

[10] CCC (Climate Change Cell) (2007) Climate Change and Bangladesh. Department of Environment, Government of the People's Republic of Bangladesh, Dhaka.

http://www.bdresearch.org.bd/home/climate_knowledge/cd1/pdf/Bangladesh\%20and\%20climate\%20change/Climate\% 20change\%20impacts\%20,vulnerability,\%20risk/Climate\%20Change\%20And\%20Bangladesh.pdf

[11] Singh, O.P., Khan, T.M.A. and Rahman, M.S. (2000) The Vulnerability Assessment of the SAARC Coastal Region Due to Sea Level Rise: Bangladesh Case, SAARC Meteorological Research Centre (SMRC), SMRC-No. 3, SMRC Publication, Dhaka.

[12] Karim, M.F. and Mimura, N. (2008) Impacts of Climate Change and Sea-Level Rise on Cyclonic Storm Surge Floods in Bangladesh. Global Environmental Change, 18, 490-500. http://dx.doi.org/10.1016/j.gloenvcha.2008.05.002

[13] BBS (2011) Population Census. Bangladesh Bureau of Statistics, Dhaka.

[14] Islam, M.R. (2004) Where Land Meets the Sea: A Profile of the Coastal Zone of Bangladesh. The University Press Limited, Dhaka.

[15] Gowing, J.W., Tuong, T.P. and Hoanh, C.T. (2006) Land and Water Management in Coastal Zones: Dealing with Agriculture-Aquaculture-Fishery Conflicts. Environmental Livelihoods in Tropical Coastal Zones: Managing Agriculture-Fishery-Aquaculture Conflicts.

[16] World Bank (2000) Bangladesh: Climate Change \& Sustainable Development. Report No. 21104 BD, Dhaka. http://www-wds.worldbank.org/external/default/WDSContentServer/WDSP/IB/2001/04/13/000094946_01033105302 920/Rendered/PDF/multiopage.pdf

[17] Sarwar, G.M. (2005) Impacts of Sea Level Rise on the Coastal Zone of Bangladesh. Unpublished Master's Thesis, Lund University, Lund.

[18] NAPA (National Adaptation Programme of Action of Bangladesh) (2005) Ministry of Environment and Forest (MoEF), Government of the People's Republic of Bangladesh.

[19] Miller, G.T. (2004) Living in the Environment. Brooks/Cole-Thomson Learning, Pacific Grove. 
[20] Ahmed, A.U. (2008) Assessment of Vulnerability to Climate Change and Adaptation Options for the Coastal People of Bangladesh. Practical Action, Dhaka.

[21] ICZMP (Integrated Coastal Zone Management Plan) (2003) Delineation of the Coastal Zone. WP005, Dhaka. http://www.warpo.gov.bd/rep/wp005/wp005.PDF

[22] MoWR (Ministry of Water Resources) and GoB (2003) Knowledge Portal on Estuary Development. WP 017 Integrated Coastal Zone Management Plan Project, WARPO and CEGIS, Dhaka.

[23] SRDI (Soil Research Development Institute) (2001) Soil Resources in Bangladesh: Assessment and Utilization. Dhaka.

[24] UNEP (United Nations Environment Programme) (1989) Criteria for Assessing Vulnerability to Sea-Level Rise: A Global Inventory for High-Risk Areas. Delft Hydraulics Laboratory, Delft and United Nations Environment Programme, Nairobi.

[25] Shamsuddoha, M. and Chowdhury, R.K. (2007) Climate Change Impact and Disaster Vulnerabilities in the Coastal Areas of Bangladesh. COAST Trust, Dhaka.

[26] Miah, M.U. (2008) Assessing Long-Term Impacts of Vulnerabilities on Crop Production Due to Climate Change in the Coastal Areas of Bangladesh. Bangladesh Centre for Advanced Studies, Dhaka.

[27] Khan, A.E., Ireson, A., Kovats, K., Mojumder, S.K., Khusru, A., Rahman, A. and Vinies, P. (2011) Drinking Water Salinity and Maternal Health in Coastal Bangladesh: Implication of Climate Change. Environmental Health Perspective, 119, 1328-1332. http://dx.doi.org/10.1289/ehp.1002804

[28] Ali, A. (1999) Climate Change Impacts and Adaptation Assessment in Bangladesh. Climate Research, 12, $109-116$. http://dx.doi.org/10.3354/cr012109

[29] Mirza, M.M.Q. (1998) Diversion of the Ganges Water at Farakka and Its Effects on Salinity in Bangladesh. Environmental Management, 22, 711-722. http://dx.doi.org/10.1007/s002679900141

[30] Islam, M.R. (2004) Where Land Meets the Sea: A Profile of the Coastal Zone of Bangladesh. The University Press Limited, Dhaka.

[31] SRTT (Sir Ratan Tata Trust \& Navajbai Ratan Tata Trust) (2011) Salinity Prevention and Mitigation Initiative. http://www.srtt.org/downloads/salinity.pdf

[32] Bauder, T.A., Waskom, R.M. and Davis, J.G. (2007) Irrigation Water Quality Criteria, Crop Series Irrigation, Number. 0.506. http://cospl.coalliance.org/fez/eserv/co:6315/ucsu2062205062007internet.pdf

[33] http://www.soilfirst.com/

[34] Schleiff, U. (2005) Research Aspects for Crop Salt Tolerance under Irrigation with Special Reference to Root Environment. Landbauforschung Volkenrode, Special Issue 286. http://literatur.vti.bund.de/digbib_extern/dk036250.pdf

[35] Lantzke, N. (2004) Water Salinity and Crop Irrigation. Department of Agriculture, Government of Western Australia, No.34/2004. http://www.ecohydrology.uwa.edu.au/ data/page/135532/Water Salinity and Crop Irrigation.pdf

[36] Gale, J., Koenig, R. and Barnhill, J. (2001) Managing Soil Ph in Utah. Utah State University, No. AG-SO-07. http://extension.usu.edu/files/publications/publication/AG-SO-07.pdf

[37] Hoffmann, H. (2010) Soil pH and Plant Health in the Home Garden. Government of Western Australia, Note: 174. http://www.agric.wa.gov.au/objtwr/imported_assets/content/pw/gard/ph.pdf

[38] Food and Agriculture Organization of the United Nations (FAO) (2011) Water Quality for Agriculture. http://www.fao.org/DOCREP/003/T0234E/T0234E02.htm

[39] Grattan, R.S. (2002) Irrigation Water Salinity and Crop Production. University of California, FWQP Reference Sheet 9.10. http://ucanr.org/freepubs/docs/8066.pdf

[40] Amacher, J.K., Koenig, R. and Kitchen, B. (2000) Salinity and Plant Tolerance. Utah State University, No. AG-S0-03. https://extension.usu.edu/files/publications/publication/AG-SO-03.pdf 